\title{
Manajemen strategik peningkatan mutu lembaga pendidikan Muhammadiyah di Kabupaten Gunungkidul
}

\author{
Ahmad Nurdin Kholili ${ }^{1}$ *, Syarief Fajaruddin ${ }^{2}$ \\ ${ }^{1}$ Universitas Muhammadiyah Yogyakarta. \\ J1. Brawijaya, Geblagan, Tamantirto, Bantul, Daerah Istimewa Yogyakarta 55183, Indonesia. \\ ${ }^{2}$ Pascasarjana, Universitas Negeri Yogyakarta. \\ Jl. Colombo No. 1, Karang Malang, Depok, Sleman, Daerah Istimewa Yogyakarta 55281, Indonesia. \\ kholili.ahmadnurdin@gmail.com \\ * Corresponding Author
}

\section{ARTICLE INFO}

\section{Article History}

Received:

10 May 2020;

Revised:

8 June 2020;

Accepted:

13 July 2020

\section{Keywords}

Muhammadiyah;

Mutu lembaga;

Manajemen strategik;

Institution quality;

Strategic management

\begin{abstract}
Penelitian ini bertujuan untuk: 1.) Mengkaji implementasi manajemen strategik peningkatan mutu lembaga pendidikan Muhammadiyah di SMP Al-Mujahidin dan SMP Muhammadiyah Semin Kabupaten Gunungkidul; dan 2.) Menemukan formulasi alternatif manajemen strategik lembaga pendidikan Muhammadiyah dalam meningkatkan mutu sekolah di Kabupaten Gunungkidul. Penelitian ini adalah penelitian studi kasus yang bersifat kualitatif, dengan mengunakan metode observasi, interview dan dokumentasi terhadap dua lembaga pendidikan Muhammadiyah. Teknik analisis data menggunakan teori Miles dan Huberman dengan tahapan reduksi data, penyajian data dan kesimpulan. Hasil penelitian menunjukkan bahwa implementasi manajemen strategik yang dilakukan oleh SMP Muhammadiyah Al-Mujahidin dan SMP Muhammadiyah Semin melibatkan semua stakeholder. Sekolah terlebih dahulu merumuskan visi misi sekolah dengan mempertimbangkan faktor internal dan eksternal lingkungan sekolah, dilanjutkan merumuskan tujuan dan target mutu sekolah diikuti dengan penentuan strategi yang akan digunakan oleh sekolah demi terealisasinya semua target mutu yang disepakati. Implementasi strategi yang dilakukan SMP Muhammadiyah Al-Mujahidin dan SMP Muhammadiyah Semin dalam meningkatkan mutu sekolah adalah dengan menjabarkan dan melaksanakan semua strategi yang telah dirumuskan dalam bentuk kegiatan-kegiatan terprogram dan terukur. Evaluasi strategi yang digunakan SMP Muhammadiyah Al-Mujahidin dan SMP Muhammadiyah Semin adalah melalui rapat formal maupun informal.
\end{abstract}

The objective of the present study is to: 1.) Review the implementation of strategic management for the improvement of the Muhammadiyah educational institution quality in the context of Al-Mujahidin Junior High School and Muhammadiyah Junior High School Semin, the Regency of Gunungkidul; and 2.) Identify the alternative formula for the implementation of the strategic management within the Muhammadiyah educational institution quality toward the improvement of the school quality in the Regency of Gunungkidul. The nature of the study is qualitative research using observation, interview, and documentation with two Muhammadiyah educational institutions as the objects of the study. Throughout the data analysis, the technique that has been implemented is the data analysis technique proposed by Miles \& Huberman under the following sequence: (1) data reduction; (2) data presentation; and (3) conclusions. The results of the study show that the implementation of strategic management by the Al-Mujahidin Junior High School and the Muhammadiyah Junior High School Semin has involved all stakeholders. The two Muhammadiyah educational institutions formulate the school vision and the school mission in the very first place with considerations toward the internal factors and the external factors of the school environment. Then, the two Muhammadiyah educational institutions proceed to the formulation of the objectives and the targets for the school quality followed by the definition of the school strategy in achieving all of the quality targets that have been formulated. Furthermore, the strategic management by the Al-Mujahidin Junior High School and the Muhammadiyah Junior High School Semin in improving the school quality is elaborating and implementing all strategies that have been formulated in the form of programmed and measured activities. The strategies will be evaluated by the Al-Mujahidin Junior High School and the Muhammadiyah Junior High School Semin through the mechanism of both formal and informal meetings.

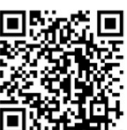

This is an open access article under the CC-BY-SA license.

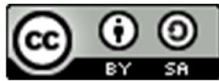

How to cite:

Kholili, A. N., \& Fajaruddin, S. (2020). Manajemen strategik peningkatan mutu lembaga pendidikan Muhammadiyah di Kabupaten Gunungkidul. Jurnal Akuntabilitas Manajemen Pendidikan, 8(1), 53-69.

doi:https://doi.org/10.21831/jamp.v8i1.31630 


\section{PENDAHULUAN}

Perkembangan maju tidaknya suatu negara dapat dilihat dari salah satu aspek yaitu aspek pendidikan (Novalita, 2019). Perkembangan pendidikan merupakan tolak ukur bagaimana bangsa dapat berkembang dengan baik, untuk itu diperlukan upaya-upaya strategis dan terarah untuk meningkatkan kualitas dan mutu dari pendidikan tersebut. Mengutip seorang ahli pendidikan, lebih spesifik tokoh manajemen dan kebijakan pendidikan, Fullan (1994) bahwa "yesterday's scores will not win tomorrow's ball games." Ini menggambarkan bahwa pendidikan begitu sangat penting dan strategis untuk mempersiapkan generasi baru mampu hidup dan sukses menjalani kehidupan di masa depan (Husna, 2019; Kurniyati, 2019; Rosado, 2004; Zamroni, 2011). Bahkan kehancuran suatu negara dan bangsa pun ditentukan oleh kondisi mutu dan kualitas pendidikan negara dan bangsa tersebut.

Untuk terjaminnya kualitas pendidikan, dibutuhkan kinerja yang serius dan konsisten, terutama penyelenggara pendidikan formal (sekolah dan perguruan tinggi), pemerintah pusat dengan dinahkodai dari Kementerian Pendidikan Nasional maupun pemerintah daerah serta peran serta masyarakat sekitar serta orang tua peserta didik. Sebab, dalam sistem pendidikan saat ini, peningkatan mutu dan kualitas pendidikan tidak hanya dibebankan pada sekolah dan kementerian pendidikan yang terkait, tetapi menjadi tanggung jawab bersama antara berbagai unsur sekolah termasuk masyarakat sekitar. Oleh karena itu, peran serta masyarakat dan tokoh masyarakat harus senantiasa ikut serta dan pro-aktif terhadap peningkatan mutu dan kualitas pendidikan. Untuk menjamin dan peningkatan mutu dan kualitas pendidikan agar lebih terukur dan terarah, diperlukan kegiatan yang terprogram dengan baik, direncanakan dan dapat diukur dalam wujud manajemen mutu yang salah satunya adalah manajemen strategik.

Satu diantara lembaga pendidikan terbesar di Indonesia salah satunya adalah Muhammadiyah atau yang disebut Amal Usaha Muhammadiyah (AUM) bidang Pendidikan (Subarkah, 2017). Peningkatan kualitas pendidikan diawali dari menanamkan kesadaran tentang pentingnya pendidikan serta kemampuan sumber daya manuasia dan yang jauh lebih penting adalah pengembangan watak bangsa untuk memiliki kesadaran memajukan kulitas dan mutu Pendidikan (Kurniawan, 2017; Mulyana, 2004). Peran Muhammadiyah dalam pendidikan dalam misi sekolah dengan basis keislaman lebih komplek dan komprehensif dari pada pendidikan umum (Qomar, 2013). Ada dua prioritas tujuan yang dilaksanakan oleh sekolah yang berbasis Islam yaitu peningkatan akademik dan peningkatan nilai pengamalan keagamaan (Qomar, 2013; Umam, 2017). Dua tujuan tersebut yang harus diwujudkan oleh setiap sekolah yang berbasis pondasi nilai Islam, termasuk lembaga pendidikan Muhammadiyah jika ingin menjadi lembaga yang unggul.

Dalam perkembangannya, lembaga-lembaga pendidikan Islam termasuk Amal Usaha Muhammadiyah bidang pendidikan mulai bertebaran dimana-mana hingga ke pelosok desa. Akan tetapi beberapa lembaga pendidikan dalam yayasan Muhammadiyah tidak berkembang dengan cepat dan cenderung mengalami penurunan. Perkembangan lembaga yang begitu pesat dari jumlah sekolah, namun dari segi terjaminnya kualitas dan mutu tidak mengalami kenaikan yang besar dan cenderung stagnan dari segi manajemen pengelolaan. Hal tersebut, karena masih dijumpai sekolah yang dimiliki oleh Muhammadiyah menjadi bukan pilihan pertama bagi masyarakat (Sagala, 2013). Penyebab perkembangan pendidikan tidak merata menurut Mursidi $(2010,2013)$ dipengaruhi oleh tiga faktor utama yaitu: 1.) Kebijakan pemerintah dalam penyelenggaraan pendidikan yang sering berubah dan tidak konsekuen dalam penerapannya; 2.) Penyelenggaraan pendidikan yang tersentral di pusat, sehingga segala kebijakan tentang pendidikan ditentukan oleh pemerintah pusat; dan 3.) Kesadaran kerjasama dalam membangun sekolah sangat kurang, yang meliputi kerjasama pihak sekolah, orang tua dan masyarakat sekitar.

Sekolah yang berada dalam lingkungan Muhammadiyah meningkatan mutu pendidikan dengan cara merealisasikan peraturan pemerintah melalui tiga aspek pengelolaan. Aspek yang pertama adalah sekolah Muhammadiyah harus mampu mencukupi kebutuhan pendidikan masyarakat baik dari lapisan paling bawah sampai lapisan atas serta untuk semua jenjang. Selanjutnya mutu dan daya saing lulusan sekolah Muhammadiyah harus terjamin dapat diterima oleh semua aspek masyarakat. Aspek yang ketiga adalah sekolah Muhammadiyah harus efisien dan akuntabilitas dalam 
mengelola pendidikan. Efisien dan akuntabilitas dalam pengelolaan aggaran juga efektif dalam proses belajar mengajar (Hamid, Sairin, \& Nasir, 2005).

Permasalahan yang timbul terhadap kualitas mutu sekolah Muhammadiyah adalah mengenai seberapa baik proses penyelenggaraan dan pengelolaan sekolah Muhammadiyah, bagaimana standarisasi mutunya, dan bagaimana kualitas mutu lulusan yang dihasilkannya. Permasalahan tersebut dapat terpecahkan sekaligus memberikan kepastian mutu pendidikan dengan sekolah senantiasa melakukan berbagai macam inovasi terutama dalam hal manajemen strategik dalam peningkatan mutu sekolah menuju perbaikan secara terus menerus. Menurut pendapat Aziz (2015) setiap sekolah harus senantiasa melakukan berbagai macam perubahan dan perbaikan terhadap manajemen yang dimulai dengan perencanaan atau planning. Melalui perencanaan yang tepat sudah akan tergambarkan hasil yang ingin dicapai (Darmadji, 2008; Rahayuningsih, Fajaruddin, \& Manggalasari, 2018). Dengan itu, nantinya tujuan pendidikan dapat terwujud dengan maksimal, khususnya tujuan Amal Usaha Muhammadiyah bidang pendidikan.

Bahkan menurut Prim Masrokan, semua jenjang dan jenis lembaga pendidikan Islam termasuk Amal Usaha Muhammadiyah bidang pendidikan perlu adanya strategi penerapan manajerial yang seefektif dan setepat mungkin, sehingga pendidikan Islam dalam hal ini Amal Usaha Muhammadiyah bidang pendidikan dapat semakin meningkat dan memiliki daya saing secara kompetitif dengan lembaga pendidikan lain, sehingga sekolah Muhammadiyah dapat diterima dengan baik di masyarakat dan mutu pendidikan semakin meningkat (Hambali \& Luthfi, 2017; Mutohar, 2013). Realitas seperti itulah yang terjadi saat ini terhadap Amal Usaha Muhammadiyah bidang pendidikan di Kabupaten Gunungkidul. Ini terlihat dari banyaknya jumlah Amal Usaha Muhammadiyah bidang pendidikan yang berjumlah 3 sekolah untuk tingkat SMA, sebelas sekolah untuk tingkat SMK dan 26 sekolah untuk tingkat Sekolah Menengah Pertama (SMP/MTs).

Setelah peneliti melakukan wawancara awal dan diskusi dengan pimpinan majelis Dikdasmen PDM Kabupaten Gunungkidul, setidaknya ada beberapa persoalan yang saat ini sedang dihadapi oleh sekolah Muhammadiyah, diantaranya: 1.) Kondisi sekolah Muhammadiyah yang selalu menjadi pilihan kedua (second alternative) setelah sekolah negeri. Ini terlihat dari siswa-siswa yang sebelumnya sudah mendaftar ke sekolah Muhammadiyah, namun karena belum terpenuhinya kuota sekolah negeri maka mereka menarik kembali persyaratan yang sudah masuk; 2.) Perkembangan mutu sekolah Muhammadiyah yang lambat bahkan bisa dikatakan stagnan. Ini terlihat dari proses pelaksanaan dan output lulusan yang ada di sekolah Muhammadiyah, khususnya prestasi belajar dan non akademik yang diraih beberapa tahun terakhir; dan 3.) Manajemen sekolah yang masih tertinggal jauh dari sekolah lain, terutama dari sekolah negeri. Ini terlihat dari keterlibatan semua elemen dan partisipasi masyarakat sekitar yang masih kurang, padahal dalam manajemen yang baik bahwa untuk menghasilkan mutu sekolah yang baik dibutuhkan partisipasi dan keterlibatan semua unsur masyarakat.

Menurut Zamroni (2011) ada beberapa faktor lain yang menjadikan Amal Usaha Muhammadiyah bidang pendidikan ini mengalami perkembangan yang relatif stagnan, diantaranya: 1.) Kurang kesadaran dan pemahaman akan peran lembaga pendidikan, baik sekolah maupun perguruan tinggi Muhammadiyah sebagai bagian dari gerakan dakwah Islam mengajak umat untuk berbuat kebajikan dan mencegah kemungkaran; 2.) Lembaga pendidikan Muhammadiyah cenderung dilaksanakan secara apa adanya, kurang memiliki "greget" untuk menghadirkan yang terbaik: 3.) Pengelolaan kurang disiplin dan masih terdapat yang kurang amanah; 4.) Kurang ikhlas dan senang jabatan; 5.) Kehilangan watak tajdid; 6.) Kurang kebersamaan; 7.) Tidak ada upaya kaderisasi pengelola amal usaha; dan 8.) Kurang memiliki daya juang dan tumpang tindih antara pengelola dan pimpinan persyarikatan (Hamid, Sairin, \& Nasir, 2005; Zamroni, 2011).

Dari sekian banyak Amal Usaha Muhammadiyah bidang pendidikan saat ini, khususnya tingkat SMP/MTs di Kabupaten Gunungkidul, Daerah Istimewa Yogyakarta, ada dua sekolah milik Muhammadiyah yang menarik untuk diteliti karena memeliki kualitas yang baik namun berbeda wilayah. Dua lembaga tersebut adalah SMP Al-Mujahidin yang berada di Desa Logandeng, Kecamatan Playen dan SMP Muhammadiyah Semin di Kabupaten Gunungkidul. SMP Al-Mujahidin adalah salah satu bentuk pelayanan kepada masyarakat di bidang pendidikan yang berada di perkotaan yaitu di Jalan Wonosari-Yogyakarta Km. 5, Logandeng, Playen, Plumbon Kidul, Logandeng, Kabupaten Gunung Kidul, Daerah Istimewa Yogyakarta. Dengan menerapkan program 
unggulan full day dan boarding, serta ditunjang dengan infrastruktur dan tenaga pendidik profesional, SMP Al-Mujahidin ini mampu mencetak generasi yang unggul, berilmu, beriman dan bertaqwa. Sementara itu, SMP Muhammadiyah Semin adalah amal usaha Muhammadiyah di bidang pendidikan lainnya yang terletak dipedesaan yang mampu mempertahankan kuantitas dan kualitasnya apabila dibandingkan dengan sekolah-sekolah Muhammadiyah lainnya yang setingkat yang berada dipedesaan. SMP Muhammadiyah Semin ini terletak di daerah Jalan Raya Semin, Semin, Kabupaten Gunung Kidul, Daerah Istimewa Yogyakarta. Dengan berbekal visi dan misi, serta didukung dengan sarana prasarana yang memadai, SMP ini mampu mencetak generasi-generasi yang handal.

Ada beberapa keunikan lainnya dari kedua Amal Usaha Muhammadiyah tersebut sehingga peneliti tertarik melaksanakan penelitian di lokasi tersebut adalah: 1.) Kedua sekolah tersebut merupakan sekolah yang memiliki kualitas mutu pendidikan yang baik dengan dibuktikan dengan berbagi macam prestasi yang diraih baik tingkat lokal maupun sampai tingkat internasional; 2.) Memiliki manajemen mutu sekolah yang baik sehingga dua sekolah tersebut dapat bersaing dengan sekolah yang lain; 3.) Kedua Amal Usaha Muhammadiyah ini berada di dua Lingkungan yang asri, kondusif dan sportif untuk pengembangan kepribadian Islam; 4.) Adanya keterlibatan semua elemen sekolah sehingga setiap orang ingin berpartisipasi dalam pengembangan sekolah; 5.) Siswa mendapatkan bimbingan yang maksimal dibidang materi pelajaran umum, keislaman dan mental spiritual; dan 6.) Jumlah siswa dari kedua Amal Usaha Muhammadiyah ini relatif stabil bahkan meningkat, atau termasuk dalam kategori banyak.

Berdasarkan hal tersebut, kedua Amal Usaha Muhammadiyah ini sangat layak sebagai objek penelitian dengan alasan pada karekteristik yang berbeda namun memiliki kualitas dan mutu manajerial yang baik sehingga layak untuk diteliti. Oleh karena itu, untuk mengetahui sisi positif pengelolaan menajeman bahkan menemukan strategi pengelolaan yang tepat dalam meningkatkan mutu pendidikan pada Amal Usaha Muhammadiyah di bidang pendidikan saat ini, peneliti melakukan penelitian ini.

\section{METODE}

Penelitian ini mengkaji dan menganalisa implementasi manajemen strategik lembaga pendidikan Muhammadiyah dalam peningkatan mutu sekolah, maka jika ditinjau dari segi jenisnya, penelitian ini termasuk jenis penelitian studi kasus. Penelitian serupa dilakukan oleh Najib dan Pardjono (2019), Saputra (2017), Setyoningrum (2018), dan Susanto dan Wibowo (2017) dengan penelitian tentang peningkatan mutu manajemen sekolah. Metode pengumpulan data yang digunakan dalam penelitian ini yaitu: 1) Observasi berperan serta (participant observation). Observasi berperan serta dilakukan pada saat melihat langsung kondisi sekolah. Observasi mempunyai maksud untuk melakukan pengamatan secara fokus dan teliti untuk memperoleh data yang lengkap. Kegiatan ini diharapkan peneliti dapat lebih memahami perilaku secara detail dan menghasilkan data yang lebih akurat; 2.) Wawancara mendalam (in depth interview) yang diperoleh, diantaranya dari kepala sekolah, wakil kepala sekolah, tim manajemen, guru dan karyawan bahkan siswa; dan 3.) Analisis dokumen atau studi dokumentasi adalah proses pengumpulan data dengan cara mengumpulkan catatan penting yang berkaitan dengan permasalahan yang akan diteliti. Dokumen ini yang bersumber dari non insani, yaitu dokumen resmi sekolah dan dokumen pendukung lainnya. Sebagai penguat data penelitian dibutuhakan bukti fisik yang berupa dokumen atau yang lebih dikenal dengan dokumentasi. Bentuk dokumentasi berupa foto, catatan-catatan sekolah, surat atau catatan lain yang mendukung penelitian.

Adapun analisis data pada penelitian kualitatif dimulai ketika proses perencanaan, proses pengamatan ketika penelitian berlangsung, dan ketika proses pengolahan data. Menurut Miles, Huberman, dan Saldaña (2014) analisis data pada penelitian kualitatif yaitu reduksi data (data reduction), penyajian data (data display), dan kesimpulan, penarikan atau verifikasi (conclusion drawing/verification). 


\section{HASIL DAN PEMBAHASAN}

\section{Hasil}

\section{Manajemen Strategik Peningkatan Mutu Sekolah di SMP Al-Mujahidin}

Perumusan Strategi SMP Al-Mujahidin dalam Meningkatan Mutu Sekolah

Hal pertama yang dilakukan dalam perumusan strategi SMP Al-Mujahidin dalam meningkatan mutu sekolah adalah perumusan visi dan misi, penentuan tujuan dan target yang harus dicapai sekolah, dan menentukan strategi yang akan dilaksanakan untuk mencapai tujuan tersebut.

\section{Implementasi Pengembangan Kurikulum}

Pengembangan kurikulum dalam pendidikan sangatlah penting dan berfungsi untuk menentukan tujuan sekolah mau dibawa kemana sekaligus untuk mempertajam tujuan pendidikan sekolah. Sekaligus sebagai sumber rujukan dalam proses kegiatan belajar mengajar dari semua tingkat pendidikan.

\section{Implementasi Pembinaan Guru dan Karyawan}

Pembinaan terhadap guru dan karyawan adalah sebuah ikhtiar terencana yang dilakukan SMP Al-Mujahidin. Pembinaan terhadap guru dan karyawan merupakan kegiatan rutin mingguan bahkan harian agar mampu bekerja secara professional. Contoh: workshop, pengajian rutin bulanan, Baitul Arqom, dan sebagainya.

\section{Implementasi Peningkatan Prestasi Peserta Didik}

Prestasi belajar peserta didik salah satu komponen untuk mengukur berhasil atau tidaknya sekolah dalam melakukan proses pendidikan terhadap peserta didiknya. Memang banyak fakta membuktikan bahwa semakin banyak prestasi yang diraih oleh siswa di sekolah, maka semakin baik pula respon, tanggapan dan citra lembaga pendidikan tersebut dalam pandangan masyarakat. Salah satu ikhtiar yang dilakukan oleh SMP Al-Mujahidin dalam mewujudkan visi misi yang telah ditetapkan adalah adanya peningkatan siswa baik dalam bidang prestasi akademik maupun prestasi di luar akademik bahkan intelektual dan spiritual.

Tabel 1. Prestasi Siswa SMP Al-Mujahidin

\begin{tabular}{lcc}
\hline & Tingkat & Jumlah Prestasi \\
\hline Internasional & 4 kejuaraan \\
Nasional & 5 Kejuaraan \\
Propinsi & 16 kejuaraan \\
Kabupaten & 43 kejuaraan \\
Kecamatan & 55 kejuaraan \\
\hline
\end{tabular}

\section{Implementasi Menciptakan Lingkungan Sekolah yang Harmonis dan Nyaman}

Kegiatan yang dilakukan SMP Al-Mujahidin dalam mewujudkan kultur atau lingkungan yang baik, yang harmonis dan nyaman baik bagi guru dan karyawan ataupun bagi peserta didik, diantaranya dengan kegiatan 3S (senyum, salam dan sapa) dan 7K (keamanan, ketertiban, keindahan, kebersihan, kerindangan, kekeluargaan dan kesehatan). Dengan adanya program-program tersebut, lingkungan yang baik, harmonis dan nyaman dapat terwujud dengan baik. Semua guru, karyawan dan peserta didik bagaikan sebuah keluarga sehingga dalam melaksanakan tugas apapun selalu mendapat kemudahan.

\section{Implementasi Studi Banding ke Sekolah Unggulan}

Hasil observasi dan studi dokumentasi ke bagian tata usaha, di ruang tata usaha peneliti diperlihatkan dokumentasi-dokumentasi studi banding yang pernah dilakukan SMP Al-Mujahidin ke sekolah-sekolah unggulan baik dalam negeri maupun luar negeri, baik berupa foto-foto, daftar 
peserta study banding dan kegiatan-kegiatannya. Memang, bagi sekolah yang ingin selalu mengembangkan mutu dan kualitasnya, studi banding merupakan salah satu ikhtiar yang harus dilakukan sekolah sehingga sekolah tersebut selalu memiliki motivasi untuk berkompetisi dan bersaing dengan sekolah lainnya. Walau dilihat dari anggaran yang dibutuhkan, studi banding membutuhkan biaya yang cukup besar. Namun, pengorbanan yang dikeluarkan sekolah itu tidak akan sia-sia karena paling kegiatan tersebut tidak akan meningkatkan motivasi bagi keluarga sekolah untuk selalu meningkatkan mutu sekolah demi tercapainya visi dan misi yang telah diformulasikan

Evaluasi Strategi SMP Al-Mujahidin dalam Meningkatkan Mutu Sekolah

\section{Evaluasi Manajemen Strategik}

Proses evaluasi strategi yang dilakukan SMP Al-Mujahidin berupa evaluasi secara informal maupun formal, baik berupa evaluasi internal di setiap bidang ataupun evaluasi menyeluruh. Evaluasi ini dilakukan untuk mengetahui persoalan dan kendala yang dihadapi oleh masing-masing bidang. Dan untuk evaluasi menyeluruh biasanya melibatkan semua elemen sekolah agar bisa mengetahui persoalan yang dihadapi secara utuh, solusi dan tindak lanjutnya.

\section{Evaluasi Strategi Pengembangan Kurikulum}

Dalam evaluasi strategi pengembangan kurikulum ada kendala yang ditemukan yaitu adanya guru yang kurang inovatif dalam menggunakan metode pembelajaran sehingga peserta didik merasa bosan. Adapun solusi yang dilakukan adalah dengan melakukan pendampingan dan pembinaan secara intensif terhadap guru baik internal maupun eksternal.

\section{Evaluasi Strategi Pembinaan Guru dan Karyawan}

Bagi SMP Al-Mujahidin, pendampingan dan pembinaan rutin terhadap guru dan karyawan adalah hal yang sangat penting. Ini dibuktikan dengan adanya pendampingan dan pembinaan secara rutin terhadap guru dan karyawan demi menjaga mutu sekolah. Pembinaan itu dilakukan internal sekolah maupun eksternal.

\section{Evaluasi Strategi Peningkatan Prestasi Peserta Didik}

Dalam mengevaluasi strategi peningkatan prestasi peserta didik, kepala sekolah menyampaikan bahwa di SMP Al-Mujahidin prestasi peserta didik itu sangat penting, karena ini ada hubungannya dengan keberlangsungan sekolah, sehingga di SMP Al-Mujahidin ada program One Student One Medalion, satu siswa mendapatkan satu medali.

\section{Evaluasi Strategi Menciptakan Lingkungan Hidup Yang Harmonis}

Program menciptakan lingkungan yang harmonis di SMP Al-Mujahidin dapat berjalan dengan baik dan cukup memuaskan. Kendati ada sedikit kendala namun masih bisa diselesaikan dengan adanya pembinaan guru dan karyawan.

\section{Evaluasi Strategi Studi Banding ke Sekolah Unggulan}

Di SMP Al-Mujahidin, studi banding ke sekolah unggulan merupakan hal yang rutin dilakukan baik dalam negeri maupun ke luar negeri. Kesimpulan yang dapat peneliti sampaikan bahwa implementasi manajemen strategik peningkatan mutu yang dilakukan oleh SMP AlMujahidin adalah dengan melibatkan semua stakeholder dalam setiap tahapan manajemen strategik. Dalam merumuskan strategi, sekolah terlebih dahulu merumuskan visi misi sekolah, dilanjutkan merumuskan tujuan dan target mutu sekolah diikuti dengan penentuan strategi yang akan digunakan oleh sekolah demi terealisasinya semua target mutu yang disepakati. Adapun implementasi strategi yang dilakukan dalam meningkatkan mutu sekolah adalah dengan menjabarkan dan melaksanakan semua strategi yang telah dirumuskan dalam bentuk kegiatan-kegiatan terprogram dan terukur. Dan tahapan terakhir, evaluasi strategi yang digunakan adalah melalui rapat formal maupun informal. 


\title{
Manajemen Strategik Peningkatan Mutu Sekolah di SMP Muhammadiyah Semin
}

\author{
Perumusan Strategi SMP Muhammadiyah Semin dalam Meningkatkan Mutu Sekolah
}

Hal pertama yang dilakukan dalam perumusan strategi SMP Muhammadiyah Semin dalam meningkatan mutu sekolah adalah perumusan visi dan misi. Perumusan visi dan misi SMP Muhammadiyah Semin dilakukan melalui proses pengodokan dari sejak lama. Karena usia SMP Muhammadiyah Semin yang relatih sudah lebih dari 30 tahun visi dan misi tidak mengalami begitu banyak perubahan. Penyusunan visi dan misi SMP Muhammadiyah Semin dilakukan setiap melalui rapat kerja dengan mempertimbangkan kelayakan visi dan misi tahun sebelumnya. Apabila masih relevan maka masih menggunakan visi dan misi tahun sebelumnya. Apabila kurang relevan maka dilakukan perubahan, perubahan saat ini yang paling meninjol adalah perubahan tentang jumlah juz untuk hafalan Al-Quran sebesar $2 j u z$ ini merupakan terobosan baru untuk meningkatkn kualitas mutu SMP Muhammadiyah Semin.

Selanjutnya dilakukan perumusan tujuan dan strategi sekolah dalam melaksanakan visi dan misi untuk SMP Muhammadiyah Semin dilaksanakan dengan melalui rapat koordinasi dengan semua kompenen yang ada. Adapun target dan tujuan SMP Muhammadiyah Semin adalah mengembangkan kelas khusus untuk tahfidz Al-Quran sebanyak 2 juz sebagai target utama lulusan, yang kedua adalah mengembang-kan pengamalan peribadahan secara praktek dan dilakukan pembiasaan setiap hari. Dengan pembiasaan ini diharapkan dirumah anak dapat mempraktekkan dengan baik. Selanjutnya target dan tujuan yang hendak dicapai pembiasaan perilaku yang baik untuk menunjang prestasi yang ada seperti membaca dan menabung serta kegiatan yang lain yang mendukung prestasi. Tidak kalah pentingnya yaitu menanamkan pembiasaan perilaku yang baik dalam kehidupan anak sehari-hari.

Di SMP Muhammadiyah Semin perumusan strategi disusun melalui rapat koordinasi bersama yang melibatkan hamper semua unsur yang ada, penyusunan dimulai dari pelaksanaan kurikulum dengan memprogramkan program kerja yang akan dilakukan, prosedur kegiatan tersebut serta evaluasi yang akan dilaksanakan. Strategi unggulan yang dimiliki untuk peningkatan mutu sekolah adalah kegiatan tahfidz Al-Quran $2 j u z$ yang tidak berbasis pondok pesantren, melaksanakan berbagai kegiatan ektrakurikuler, program sukses ujian nasional serta adanya penjaminan guru mengajar sesuai jam yang bersangkutan. untuk meningkatkan prestasi terutama ektrakurikuler dilakukan dengan mendatangkan guru yang profesional dibidangnya.

\section{Implementasi Strategi SMP Muhammadiyah Semin dalam Meningkatkan Mutu Sekolah}

\section{Implementasi Pengembangan Kurikulum}

Pengembangan kurikulum di SMP Muhammadiyan Semin dibahas oleh tim khusus, dalam tim tersebut dirumuskan pengembangan kurikulum apa yag akan dibahas mulai pembelajaran rutin di kelas, program ektrakurikuler beserta program khusus apa yang akan dilaksanakan. Setelah itu tim akan menyampaikan hasil rumusan kepada kepala sekolah untuk diadakan revisi bersama. Setelah jadi kemudian disampaikan kepada semua guru dan pegawai untuk diadakan pembahasan bersama apa yang harus direvisi dan apa yang harus ditambah. Hasilnya rapat nantinya dijadikan sebagai keputusan bersama yang harus dilaksanakan.

\section{Implementasi Pembinaan Guru dan Karyawan}

Pembinaan terhadap guru dan karyawan di SMP Muhammadiyah Semin dilakukan dengan cara: 1.) Koordinasi dan evaluasi mingguan yang dilaksanakan setelah upacara sebelum kegiatan belajar mengajar dimulai; 2.) Koordinasi dan evaluasi bulanan dilaksanakan bersamaan dengan pentasharufan honor awal bulan; 3.) Adanya supervisi rutin dari kepala sekolah dua kali dalam satu semester; dan 4.) dan pembinaan setiap awal semester. Pembinaan biasanya diisi oleh Majelis Dikdasmen PDM dan pengawas sekolah. 


\section{Implementasi Peningkatan Prestasi Peserta Didik}

Salah satu ikhtiar yang dilakukan oleh SMP Muhammadiyah Semin dalam mewujudkan visi misi yang telah ditetapkan adalah adanya peningkatan siswa baik dalam bidang prestasi akademik maupun prestasi di luar akademik bahkan intelektual dan spiritual. Adapun strategi untuk meningkatkan prestasi yaitu melakukan bimbingan secara khusus bagi siswa tertentu dengan cara dipanggilkan guru dari lembaga kursus seperti Primagama. Sedangkan kegiatan ektrakurikuler, Tahfidz Quran disiapkan guru tahfidz.

\section{Implementasi Menciptakan Lingkungan Sekolah yang Nyaman}

Untuk mewujudkan lingkungan yang harmonis dimulai dengan menjaga hubungan yang baik antar guru dan pegawai serta dengan siswa sehingga suasana kekeluargaan dapat tercipta dengan baik. Selain itu untuk aspek keindahan dan kenyamanan SMP Muhammadiyah Semin sering melakukan kegiatan menjaga kebersihan dengan cara kerja bakti dan keseharian menerapkan pola hidup bersih kepada semua komponen yang ada.

\section{Implementasi Studi Banding ke Sekolah Unggulan}

Bagi SMP Muhammadiyah Semin, kegiatan studi banding ke sekolah unggulan lainnya pernah dilakukan tapi dengan intensitas yang tidak rutin, disebabkan karena keterbatasan anggaran yang di miliki.

Evaluasi Strategi SMP Muhammadiyah Semin dalam Meningkatkan Mutu Sekolah

\section{Evaluasi Manajemen Strategik}

Dalam manajemen strategik, evaluasi strategi merupakan bagian yang tidak terpisahkan dengan proses-proses lainnya seperti perumusan strategi dan implementasi strategi. Itu semua dikarenakan evaluasi strategi merupakan semua ikhtiar yang dilakukan sebuah organisasi atau lembaga pendidikan dalam melakukan evaluasi dan monitoring terhadap proses perumusan strategi dan implementasi strategi sehingga semua yang telah dirumuskan dapat terlihat dan terukur, bahkan dapat dilakukan perbaikan apabila diperlukan. Selain itu apabila dirasa perlu diadakan evaluasi secara mendadak untuk memastikan program tersebut terlaksana dengan baik dan lancar.

\section{Evaluasi Strategi Pengembangan Kurikulum}

Evaluasi strategi pengembangan kurikulum ada kendala yang ditemukan yaitu adanya guru yang kurang inovatif dalam menggunakan metode pembelajaran sehingga peserta didik merasa bosan. Adapun solusi yang dilakukan adalah dengan melakukan pendampingan dan pembinaan secara intensif terhadap guru baik internal maupun eksternal.

\section{Evaluasi Strategi Pembinaan Guru dan Karyawan}

Bagi SMP Muhammadiyah Semin, pendampingan dan pembinaan rutin terhadap guru dan karyawan adalah hal yang sangat penting. Ini dibuktikan dengan adanya pendampingan dan pembinaan secara rutin terhadap guru dan karyawan.

\section{Evaluasi Strategi Peningkatan Prestasi Peserta didik}

Program peningkatan prestasi peserta didik dapat berjalan sesuai harapan dan target. Adapun kendalanya tidak semua anak memiliki kemampuan yang bagus dan terbentur dengan pembiayaan yang ada.

\section{Evaluasi Strategi Menciptakan Lingkungan Hidup Yang Harmonis}

Implementasi program menciptakan lingkungan yang harmonis di SMP Muhammadiyah Semin berjalan cukup baik dan memuaskan, walau ada sedikit kendala yang dihadapi. Strategi keharmonisan dan kenyamanan sangat terjaga, suasana belajar nyaman, lingkungan bersih serta hubungan antar guru, siswa, pegawai dan kepala sekolah terjalin dengan baik. Dari paparan tersebut, peneliti simpulkan bahwa implementasi manajemen strategik peningkatan mutu di SMP Muhammadiyah Semin sudah mengikuti prosedur tahapan dalam manajemen strategik, hanya saja 
belum maksimal dalam keterlibatan semua stakeholder dan adanya keterbatasan pembiayaan. Tahapan merumuskan stratergi, sekolah terlebih dahulu merumuskan visi misi sekolah, dilanjutkan merumuskan tujuan dan target mutu sekolah dan penentuan strategi yang akan digunakan. Tahapan implementasi strategi yang dilakukan SMP Muhammadiyah Semin dalam meningkatkan mutu sekolah adalah dengan mengimplementasikan semua strategi yang telah dirumuskan dengan segala keterbatasannya. Dan dalam tahapan evaluasi strategi, SMP Muhammadiyah Semin menggunakan pendekatan kekeluargaan.

\section{Formulasi Alternatif Manajemen Strategik Lembaga Pendidikan Muhammadiyah di Kabupaten Gunungkidul}

\section{Perumusan Strategi Peningkatan Mutu Lembaga Pendidikan}

Perumusan strategi merupakan hal yang sangat penting bahkan ujung tombak dalam proses berjalannya sebuah lembaga. Sebaik apapun seorang pimpinan, akan berantakan manakala tidak diawali dengan sebuah formulasi strategi yang baik. Ini menegaskan bahwa perumusan strategi atau formulasi strategi sangat penting untuk keberlangsungan suatu lembaga. Perumusan strategi yang dilaksanakan oleh SMP Al-Mujahidin dan SMP Muhammadiyah Semin diawali adanya perumusan visi dan misi sekolah dengan diadakannya analisis terhadap kondisi internal serta kondisi eksternal lingkungan lembaga pendidikan.

Adapun penilaian terhadap lingkungan eksternal dapat berupa identifikasi maupun evaluasi bidang sosial, budaya, politis, ekonomis, dan teknologi, serta bidang lain yang mungkin berpengaruh pada lembaga pendidikan. Perolehan dari penilaian terhadap lingkungan eksternal adalah adanya beberapa peluang (oportunities) yang dapat dimanfaatkan lembaga dan ancaman (threats) yang perlu dihindari. Sedangkan penilaian terhadap lingkungan internal dapat menjadi acuan persepsi yang realistis tentang semua kekuatan (strength) dan kelemahan (weaknesses) milik lembaga.

Ini terlihat ketika SMP Al-Mujahidin memanfaatkan kondisi prestasi siswa yang selalu meningkat, lulusannya selalu diterima di sekolah-sekolah favorit, sumber daya manusia yang dimiliki sangat profesional dan memiliki kompetensi yang baik, serta sarana prasarana yang sangat memadai dan membanggakan sebagai sebuah kekuatan dalam mewujudkan visi dan misi yang sudah dirumuskan. Sementara respon masyarakat sangat besar terhadap lembaga dan persaingan yang ketat antar lembaga dapat dijadikan peluang untuk terus maju demi terwujudnya visi dan misi lembaga. Hal ini juga dilakukan oleh SMP Muhammadiyah Semin. Komitmen yang kuat dari SDM, sarana prasarana yang cukup memadai dapat dijadikan sebagai kekuatan, sedangkan kondisi keuangan yang minim, perkembangan anak yang semakin terpengaruh dengan budaya negatif dan persaingan yang ketat antar sekolah dijadikan sebagai peluang untuk terwujudnya visi misi yang telah dirumuskan.

Perumusan visi misi dari kedua sekolah tersebut sangat bagus dan dapat diterapkan kepada semua lembaga pendidikan Muhammadiyah di Kabupaten Gunungkidul, namun dari keduanya mempunyai kelebihan masing-masing. Dalam perumusan visi-misi sebaikanya ada perubahan setiap tahunnya mengikuti dinamika yang ada seperti yang diterapkan oleh SMP Al-Mujahidin. Namun demikian apa yang dilakukan oleh SMP Muhammadiyah Semin juga bagus mempertahankan visi dan misi yang ada demi tercapainya target dan tujuan secara konstan. Setelah visi misi diformulasikan, langkah berikutnya yang ditempuh oleh lembaga pendidikan Muhammadiyah adalah menentukan tujuan dan target. Proses memformulasikan target/sasaran dapat dilakukan dengan melihat misi dan tujuan, dilanjutkan dengan menetapkan hasil yang diharapkan kemudian menetapkan jangka waktu bagi pencapaian hasil, dan yang terakhir adalah membangun akuntabilitas.

Bagi peneliti, tujuan dan target yang diharapkan tercapai oleh kedua lembaga pendidikan Muhammadiyah telah memenuhi beberapa indikator baik waktu, kejelasan maupun peningkatan. Beberapa indikator yang sangat khusus yang dimiliki sasaran sebuah lembaga pendidikan adalah: 1.) Sasaran lembaga harus terukur; 2.) Sasaran lembaga harus spesifik karena merupakan panduan untuk lembaga pendidikan yang bersangkutan; dan 3.) Sasaran lembaga haruslah bertingkat dimana yang bawah mendukung yang atasnya. Dalam pencapaian target dan sasaran sekolah SMP Al-Mujahidin mempunyai target sasaran yang sangat bagus untuk ditiru lembaga pendidikan Muhammadiyah yang mampu memiliki komponen yang lengkap mulai dari SDM, sarana prasarana dan pembiayaan yang 
kuat. Namun apabila kemampuan lembaga pendidikan Muhammadiyah dalam kategori sedangsedang saja justru menggunakan manajemen target dan sasaran yang dimiliki oleh SMP Muhammadiyah Semin pelan tapi pasti target tidak terlalu tinggi namun dapat diterapkan dalam sekolah yang berada dipinggiran dan sekolah kecil. Target dan sasaran yang dimiliki SMP Muhammadiyah Semin dapat dijadikan rujukan sebagai lembaga pendidikan Muhammadiyah unggulan bagi lembaga pendidikan dalam katagori kecil dan sedang. Untuk lembaga pendidikan yang semua sumber daya manusia tercukupi bisa mengambil rujukan SMP Al-Mujahidin yang bergerak begitu cepat dengan target dan sasaran yang cukup tinggi.

Apabila tujuan dan target sudah diformulasikan maka langkah berikutnya yaitu menentukan strategi yang akan digunakan untuk terwujudkan visi dan misi, tujuan serta target yang telah ditetapkan. Penentuan strategi menjadi hal yang penting karena strategi adalah bentuk nyata dalam mewujudkan visi dan misi, tujuan juga target. Penentuan strategi dalam hal ini adalah menentukan trik-trik/strategi dalam rangka mewujudkan visi misi lembaga. Sehingga piminan sebuah lembaga pendidikan sebagai manajer harus benar-benar teliti dalam merumuskan strategi terbaik agar tujuan dan target dapat terealisasi. Dalam merumuskan strategi yang akan digunakan, SMP Al-Mujahidin memanfaatkan musyawarah rapat kerja untuk menyusun dan merumuskan strategi terbaiknya. Dari hasil penelitian, setidaknya ada lima strategi yang diformulasikan oleh SMP Al-Mujahidin. Strategistrategi tersebut adalah pengembangan kurikulum sesuai dengan situasi dan kondisi, pembinaan guru dan karyawan atau peningkatan SDM, peningkatan prestasi belajar peserta didik, menciptakan lingkungan sekolah yang harmonis sesama guru dan karyawan atau membangun citra/branding lembaga, studi banding ke sekolah-sekolah unggulan. Hal tersebut juga dilakukan oleh SMP Muhammadiyah Semin. Rapat kerja tahunan menjadi forum musyawarah yang sangat penting untuk membicarakan dan mendiskusikan strategi-strategi terbaik dalam meningkatkan kualitas/mutu lembaga pendidikan.

Dalam perumusan strategi kedua sekolah sama-sama sudah menerapkan manajemen strategik yang bagus, program dilaksanakan melalui panitia kecil atau tim untuk merumuskan program kerja kemudian disampaikan kepada semua komponen sekolah melalui rapat kerja dilakukan revisi program kerja. Di dalam pembuatan program kerja sudah dilengkapi mulai dari perencanaan, pelaksanaan, penganggaran biaya, pihak yang melaksanakan program kerja tersebut dan diadakan evaluasi terhadap target dan sasaran yang telah tercapai. Dari hasil analisa tersebut, peneliti menyimpulkan bahwa apabila lembaga pendidikan Muhammadiyah di Kabupaten Gunungkidul memiliki keinginan untuk meningkatkan mutu/kualitas lembaganya maka ada beberapa strategi yang harus menjadi perhatian lembaga pendidikan Muhammadiyah, yaitu pengembangan kurikulum, peningkatan sumber daya manusia, peningkatan prestasi peserta didik, dan membentuk citra atau branding lembaga pendidikan.

Implementasi Strategi Peningkatan Mutu Lembaga Pendidikan

Implementasi strategi dalam konteks manajemen strategik adalah proses merealisasikan semua strategi yang telah diformulasikan ke dalam bentuk program dan tindakan nyata. Programprogram tersebut selanjutnya dikelola sebaik mungkin agar dapat terwujud. Dalam merealisasikan sebuah strategi, pimpinan lembaga pendidikan atau kepala sekolah harus mampu mengoptimalkan seluruh sumber daya yang dimiliki untuk merealisasikan strategi-strategi yang telah ditetapkan. Menempatkan sumber daya yang dimiliki sesuai dengan kemampuannya dan memanfaatkannya dengan baik akan mampu dengan mudah mewujudkan strategi tersebut. Namun, apabila semua itu tidak dikelola dengan baik maka strategi apapun sulit untuk dapat terwujud.

Dari hasil penelitian, dalam mengimplementasikan strategi yang telah dirumuskan, SMP AlMujahidin merumuskan beberapa kegiatan-kegiatan. Teknis pelaksanaan kegiatan-kegiatan tersebut diserahkan kepada koordinator masing-masing. Dalam pelaksanaannya, kepala sekolah menggunakan sistem kontrol dengan menjalin komunikasi intensif dengan koordinator kegiatan. Sistem lain yang diterapkan oleh kepala sekolah SMP Al-Mujahidin adalah dengan melakukan pengamatan, pengawasan, dan pengecekan secara berkala. Hal senada juga dilakukan oleh SMP Muhammadiyah Semin. Strategi yang telah diformulasikan kemudian diturunkan dalam program-program nyata yang pelaksanaanya langsung dihandel oleh koordinator masing-masing, dalam hal ini adalah wakil-wakil kepala sekolah. Teknis kegiatan tersebut pun diserahkan sepenuhnya kepada wakil-wakil kepala 
sekolah namun tetap berkoordinasi dengan kepala sekolah. Kepala sekolah sebagai pemimpin tentunya hanya berperan sebagai pengawas yang terhadap setiap kegiatan. Sistem pengawasan yang dapat digunakan oleh kepala sekolah SMP Muhammadiyah Semin sangat bervariasi, diantaranya dengan melihat langsung ke lapangan dan atau dengan menemui wakil-wakil kepala sekolah.

Bagi peneliti, walau semua teknis pelaksanaan diserahkan kepada koordinator kegiatan, sebagai pimpinan sebuah lembaga apalagi lembaga pendidikan, sebaiknya setiap pimpinan harus mengetahui standar operasional setiap kegiatan yang akan dilakukan. Hal ini bertujuan untuk memudahkan dalam proses monitoring dan evaluasi. Dalam manajemen strategik setiap pimpinan sebaiknya melihat setiap proses yang terjadi secara langsung, melihat setiap dokumen-dokumen yang ada dan bahkan dapat mendengarkan pendapat-pendapat secara langsung dari yang dimonitor. Semua hasil dari pengawasan tersebut selanjutnya dapat dijadikan sebagai rujukan bagi pimpinan lembaga dalam mengevaluasi setiap program kegiatan.

Pengembangan Kurikulum

Pengembangan kurikulum bagi kedua sekolah sudah memiliki pengembangan kurikulum masing-masing. Kedua sekolah sudah menerapkan standar kurikulum yang baik, mulai dari perencanan, pembahasan kurikulum serta cara evaluasi kurikulum sudah terencana dengan baik sehingga kurikulum baik yang dikembangkan oleh SMP Al-Mujahidin mengembangkan dengan kualitas yang tinggi dan standar target yang tinggi. Pengembangan kurikulum SMP Muhammadiyah Semin menggunakan kualitas yang cukup tinggi mengukur dari kemampuan anak serta memiliki target yang cukup tinggi. Kedua sekolah tersebut dapat menjadi rujukan bagi sekolah lain dalam pengembangan kurikulum.

\section{Peningkatan Sumber Daya Manusia (SDM)}

Pengembangan pembinaan pegawai kedua sekolah tersebut sudah membimbing guru dan karyawan dengan cara peningkatan kualitas melalui bimbingan teman sejawat, seminar, loka karya. Namun, karena sumber daya berbeda untuk SMP Muhammadiyah Semin sebagian besar berusia diatas 40 tahun, maka gerakan perubahan cenderung sedikit pelan dibandingkan dengan sekolah SMP Al-Mujahidin yang sebagian besar memiliki sumber daya guru dan pegawai dibawah 30 tahun. Oleh karena itu pada SMP Al-Mujahidin energi serta semangat yang dimiliki jauh lebih besar. Kedua sekolah tersebut bisa menjadi rujukan dalam pengelolaan pegawai, bagi sekolah yang memiliki tenaga atau sumber daya masih energi dan muda dapat menggunakan strategi SMP Al-Mujahidin, namun bagi yang banyak usia diatas 40 tahun dapat digunakan manajemen SMP Muhammadiyah Semin.

Peningkatan Prestasi Peserta Didik

Dalam implementasi peningkatan peserta didik kedua sekolah sudah menerapkan kegiatan sekolah yang sama-sama bagus. Kedua sekolah tersebut sudah meningkatkan kedisiplinan. Namun beberapa perbedaan yaitu, SMP Al-Mujahidin memliki siswa yang lebih tersaring dan pilihan murid lebih banyak dan berasal dari berbagai daerah, sehingga peningkatan peserta didik untuk dipacu lebih cepat sangat mudah. Berbeda dengan sekolah SMP Muhamamdiyah Semin yang memiliki peserta didik dari wilayah Semin dan sekitarnya, sehingga kemampuan anak beraneka ragam. Kedua sekolah tersebut memacu semua siswa untuk berprestasi melalui bimbingan khusus untuk mengikuti berbagai even kejuaraan.

Kedua sekolah tersebut dapat menjadi rujukan peningkatan mutu sekolah melalui peningkatan prestasi, untuk sekolah yang memiliki pembiayaan yang tinggi dapat meniru langkah SMP Al-Mujahidin untuk mengejar prestasi sampai tingkat nasional bahkan internasional. Bagi sekolah yang memiliki pengelolaan dana yang tidak banyak dapat meniru mananjemen SMP Muhammadiyah Semin tetap memacu prestasi belajar anak sampai tingkat yang mampu untuk dilalui yaitu kabupaten, propinsi dan nasional. 


\section{Membangun Citra Lembaga}

Dalam membangun citra lembaga yang harmonis dan nyaman SMP Muhammadiyah Semin lebih relevan untuk dijadikan rujukan sebagai pengembangan sekolah yang nyaman sebab menggunakan semua komponen sekolah untuk membersihkan lingkungan serta menciptakan suasana sekolah yang lebih harmonis. Untuk penciptaan lingkungan di SMP Al-Mujahidin lebih menerapkan menggunakan teknologi AC dan pegawai yang membersihkan. Untuk itu, manajemen strategik yang dapat dikembangkan untuk lembaga pendidikan lain lebih baik mengambil dari SMP Muhammadiyah Semin yang lebih realistis dan mampu membina karakter anak untuk pola hidup bersih serta gotong royong untuk membersihkan lingkungan sekolah. Melalui pembiasaan karakter tersebut diharapkan anak dapat terbiasa dalam kehidupan sehari-hari dan dapat terbiasa di lingkungan rumah masing- masing.

\section{Evaluasi Strategi Peningkatan Mutu Lembaga Pendidikan}

Tahapan terakhir dalam manajemen strategik adalah evaluasi strategi. Bagi setiap lembaga pendidikan evaluasi strategi merupakan media untuk memperbaiki lembaga kedepannya, apalagi bagi lembaga pendidikan Muhammadiyah di Kabupaten Gunungkidul, karena dengan hasil dari proses evaluasi tersebut, pimpinan dapat mengetahui kendala yang dihadapi, sehingga dapat dengan segera menyelesaikannya dengan harapan mampu meningkatkan mutu lembaga. Evaluasi terhadap strategi yang dilakukan oleh SMP Al-Mujahidin adalah dengan mengadakan rapat rutin internal bidang dan rapat menyeluruh. Dua jenis rapat ini dimanfaatkan oleh SMP Al-Mujahidin untuk melakukan evaluasi terhadap strategi yang telah dilakukan.

Hal senada juga dilakukan oleh SMP Muhammadiyah Semin. Dalam rapat tersebut, kedua lembaga sama-sama menjadikan hasil evaluasi untuk melakukan perbaikan dengan harapan strategi yang telah dirumuskan nantinya dapat dilaksanakan dengan lebih baik. Sebagai gambaran peneliti menjelaskan secara singkat hasil mengkaji terhadap proses evaluasi strategi yang dilakukan SMP AlMujahidin dan SMP Muhammadiyah Semin dalam mengevaluasi setiap strategi peningkatan mutu lembaganya.

\section{Evaluasi Manajemen Strategik}

Dalam evaluasi manajemen strategik dalam peningkatan mutu sekolah kedua sekolah sudah mengadakan evaluasi dengan baik sehingga dapat dijadikan rujukan dari sekolah lainnya. Dimana kedua sekolah sudah menerapkan evaluasi ke semua program dan strategi, program dievaluasi setiap bulan sekali secara rutin, apabila ada kendala segera diselesaikan bersama.

\section{Evaluasi Strategi Pengembangan Kurikulum}

Dalam penerapan strategi pengembangan kurikulum kedua sekolah sudah menerapakan evaluasi terhadap proses belajar mengajar yang ada, sehingga dapat dijadikan rujukan bagi sekolah Muhammadiyah yang lain untuk ditiru. Pengembangan kurikulum dilakukan melalui proses rapat koordinasi serta bimbingan khusus bagi guru yang mengalami kendala dalam pengembangan kurikulum.

\section{Evaluasi Strategi Peningkatan SDM}

Dalam penerapan evaluasi terhadap peningkatan sumber daya manusia atau pembinaan guru dan karyawan, kedua sekolah tersebut sudah menerapkan pembinaan yang sangat bagus. Pembinaan dilakukan secara rutin bulanan dan mingguan. Apabila mendesak kedua sekolah melakukan pembinaan secara khusus terhadap pegawai yang bersangkutan. Bentuk pembinaannya antara lain: 1.) Penguatan ketika rapat koordinasi dan evaluasi rutin; 2.) Pemanggilan guru atau karyawan tertentu yg kurang tertib dan kurang disiplin; dan 3.) Diberhentikan apabila tdk ada perubahan. 


\section{Evaluasi Strategi Peningkatan Prestasi Peserta Didik}

Kedua sekolah menerapkan evaluasi strategi peningkatan prestasi yang cukup baik, prestasi yang ada dimonitoring, event-event lomba dilakukan evaluasi ketika sudah selesai. Melakukan perbaikan terhadap prestasi yang telah diraih dan akan diraih.

\section{Evaluasi Strategi Membangun Citra Lembaga}

Menurut analisis peneliti, dapat disimpulkan bahwa formulasi alternatif manajemen strategik peningkatan mutu yang harus dilakukan oleh lembaga pendidikan di Kabupaten Gunungkidul adalah dengan melibatkan semua stakeholder dalam setiap tahapan manajemen strategik. Dalam merumuskan strategi (formulating), mengimplementasikan strategi (implementating) dan mengevaluasi strategi (evaluating), semua unsur lembaga pendidikan Muhammadiyah di Kabupaten Gunungkidul harus terlibat didalamnya. Karena dengan adanya keterlibatan semua stakeholder tersebut akan mempermudah dalam meningkatkan dan mewujudkan lembaga pendidikan Muhammadiyah yang bermutu dan kompetitif.

Selain itu, ada beberapa strategi yang harus menjadi perhatian khusus lembaga pendidikan Muhammadiyah di Kabupaten Gunungkidul, yaitu pengembangan kurikulum, peningkatan sumber daya manusia dan sarana prasarana, peningkatan prestasi peserta didik dan membangun citra lembaga. Keberadaan sumber daya manusia yang masih muda dan berkualitas juga ditopang dengan anggaran biaya yang cukup besar dipastikan dapat membantu mewujudkan lembaga pendidikan Muhammadiyah di Kabupaten Gunungkidul yang bermutu.

\section{Pembahasan}

Strategi yang digunakan sebagai wujud ikhtiar dalam meningkatkan kualitas pendidikan melalui kurikulum adalah dengan mengembangkan kurikulum. Pengembangan kurikulum menjadi hal utama dalam meningkatkan mutu pendidikan. Adapun hal yang diharapkan dalam pengembangan kurikulum oleh lembaga pendidikan Muhammadiyah adalah mampu memberikan dampak positif dalam prestasi belajar siswa baik akademik maupun non akademik. Pada dasarnya pengembangan kurikulum memiliki tujuan mengarahkan kurikulum sekarang ke tujuan pendidikan yang diharapkan (Dakir, 2004; Nasir, 2013; Zahra, 2019). Oleh karena itu, kurikulum yang ada sekarang sangatlah berpengaruh terhadap tujuan pendidikan, yaitu untuk menyiapkan peserta didik meraih masa depan yang lebih baik. Dalam pengembangan kurikulum banyak hal yang harus diperhatikan dan dipertimbangkan sebelum mengambil suatu keputusan. Pembuatan keputusan yang berhubungan dengan pengembangan kurikulum merupakan proses kebijakan yang didalamnya terdapat tanggungjawab berbagai pihak yang berkepentingan dengan permasalahan pendidikan secara legal. Kadangkala ditemukan sikap pro dan kontra, yakni sikap menerima dan menolak terhadap hasil keputusan kurikulum. Hal ini mungkin dikarenakan adanya perbedaan sudut pandang mereka terhadap hasil keputusan kurikulum dan fungsi sekolah.

Selain itu, strategi yang kedua yang harus menjadi perhatian lembaga adalah meningkatkan mutu pendidikan melalui peningkatan sumber daya manusia dan sarana prasarana yang dimiliki. Peningkatan sumber daya manusia dalam hal ini adalah meningkatnya kinerja sumber daya manusia yang ada sehingga menjadi sumber daya manusia yang profesional. Sedangkan peningkatan sarana prasarana dalam konteks ini adalah peningkatan sarana prasarana pendidikan di lembaga pendidikan Muhammadiyah. Bagi Mulyasa (2002) sarana pendidikan adalah peralatan dan perlengkapan yang secara langsung dipergunakan dan menunjang proses pendidikan, khususnya proses belajar mengajar, seperti gedung, mang kelas, meja kursi, serta alat-alat dan media pengajaran. Adapun yang dimaksud dengan prasarana pendidikan adalah fasilitas yang secara tidak langsung menunjang jalannya proses pendidikan atau pengajaran, seperti halaman, kebun, taman sekolah, jalan menuju sekolah. Namun jika dimanfaatkan secara langsung untuk proses belajar mengajar, seperti taman sekolah untuk pengajaran mata pelajaran biologi dengan memanfaatkan tumbuhan yang ada, maka komponen tersebut bisa disebut sebagai sarana Pendidikan (Mulyasa, 2002; Nasokah, 2015).

Dengan demikian, betapa urgennya keberadaan sumber daya manusia dan sarana prasarana dalam sebuah lembaga pendidikan, sehingga kepala sekolah hendaknya bersungguh-sungguh dalam 
mengelola dan mendayagunakan semua potensi tersebut dengan sebaik-baiknya agar mampu memberikan hal positif demi kemajuan lembaga pendidikan Muhammadiyah. Setelah strategi peningkatan sumber daya manusia dan sarana prasarana dilakukan, maka strategi berikutnya yang akan mampu meningkatkan mutu lenbaga pendidikan Muhammadiyah adalah peningkatan prestasi belajar peserta didik. Peningkatan prestasi belajar peserta didik menjadi penting dikarenakan prestasi peserta didik merupakan salah satu faktor mutu pendidikan.

Mukhamad Ilyasin dan Nanik Nurhayati (2012) menjelaskan bahwa pendidikan yang berkualitas berdasarkan konsep relatif tentang kualitas, maka para peserta didik diharapkan menjadi pembelajar sepanjang hayat, komunikator yang baik dalam bahasa nasional dan internasional, punya keteram-pilan teknologi untuk lapangan kerja dan kehidupan sehari-hari, siap secara kognitif untuk pekerjaan yang kompleks, pemecahan masalah dan penciptaan pengetahuan, dan menjadi warga negara yang bertanggungjawab secara sosial, politik dan budaya. Intinya para siswa menjadi manusia dewasa yang bertanggungjawab akan hidupnya (Ilyasin \& Nurhayati, 2012).

Untuk mewujudkan hal tersebut maka prestasi belajar peserta didik baik akademik maupun non akademik dituntut untuk benar-benar ditingkatkan. Tanggungjawab yang besar berada dipundak kepala sekolah dan para guru untuk benar-benar mendidik para siswanya agar menjadi lulusan yang bermutu. Strategi terakhir yang harus menjadi perhatian lembaga pendidikan Muhammadiyah dalam meningkatkan mutu pendidikan adalah membangun dan membentuk branding lembaga pendidikan. Sebagai prinsip, semakin baik branding lembaga di masyarakat, maka semakin baik pula kepercayaan masyarakat terhadap lembaga tersebut. Demikian pula sebaliknya, semakin buruk branding lembaga pendidikan di masyarakat, maka semakin sedikit pula kepercayaan masyarakat kepada lembaga tersebut. Hal ini menegaskan bahwa branding sebuah lembaga pendidikan sangat berpengaruh terhadap jumlah peserta didik yang diperoleh.

Ada beberapa cara dalam membangun dan membentuk branding lembaga pendidikan yang dapat ditiru dari SMP Al-Mujahidin dan SMP Muhammadiyah Semin adalah menjalin komunikasi yang baik dengan lembaga pendidikan lainnya juga dengan masyarakat. Komunikasi yang baik lembaga pendidikan dengan masyarakat pada dasarnya merupakan media yang sangat baik dalam membina dan mengembangkan pertumbuhan pribadi peserta didik di sekolah Mulyasa, 2007). Dari paparan peneliti tersebut, jika dihubungkan dengan konsep formulasi, maka dapat diambil kesimpulan bahwa proses perumusan strategi yang dilakukan kedua lembaga pendidikan Muhammadiyah tersebut mendukung teori yang ada. Ini menjadi pelajaran yang bisa diambil oleh lembaga-lembaga pendidikan Muhammadiyah lainnya bahwa apabila lembaga pendidikan dikelola sesuai teori manajemen strategik, maka akan mampu meningkatkan mutu atau kualitas lembaga pendidikan Muhammadiyah.

Dengan demikian, dalam proses perumusan strategi ini, seorang pimpinan lembaga pendidikan hendaknya memanfaatkan semua sumber daya yang ada untuk bersama merumuskan formulasi yang efektif dan efisien dengan tujuan mengembangkan lembaga pendidikan Muhammadiyah yang dikelola. Hal ini bertujuan agar adanya rasa saling memiliki (sense of belonging) antara yang satu dengan yang lainnya, memunculkan semangat untuk selalu bertanggung jawab, sehingga setiap orang dalam lembaga tersebut mudah dalam melaksanakan semua formulasi yang telah dirumuskan dan ditetapkan bersama. Dalam dunia pendidikan, sebaiknya setiap orang memiliki hak untuk berpartisipasi dalam pengawasan pada setiap program kegiatan, karena apabila setiap orang ikut berpartisipasi dalam pengawasan, maka dengan sendirinya mereka akan dapat memberikan masukan, ide dan bahkan pertimbangan yang relevan dengan program-program yang sedang dan akan dilakukan dan dengan sendirinya program yang telah ditetapkan akan dapat dilaksanakan dengan baik dan hasilnya pun baik.

Adapun hal yang perlu diperhatikan apabila pengawasan ingin berjalan dengan efektif diantaranya: 1.) Pengawasan harus ada korelasinya dengan dengan tujuan; 2.) Kriteria yang dipergunakan harus sesuai dengan standarnya; 3.) Pengawasan hendaknya sesuai dengan sifat dan kebutuhan lembaga; 4.) Pengawasan hendaknya dibatasi, karena ini akan memiliki dampak yang negatif terhadap bawahan; dan 5.) Pengawasan sebaiknya terjadwal, mengacu pada tindakan perbaikan dan juga mengacu kepada prinsip problem solving (Fattah, 1999). Oleh sebab itu, sebagai pimpinan lembaga, selain harus mampu menempatkan seseorang sesuai kompetensinya, pimpinan 
lembaga juga harus mampu melakukan monitoring dan evaluasi dengan baik dengan harapan setiap strategi yang sedang dilaksanakan dapat berjalan sesuai dengan yang direncanakan.

Dalam melakukan evaluasi strategi membangun branding lembaga pendidikan kedua sekolah sudah menerapkan manajemen yang bagus yang dapat dikembangkan di setiap sekolah yang ada saat ini. Apabila peneliti mengkorelasikan dengan konsep evaluasi. Secara garis besar ada dua jenis evaluasi, yaitu: 1.) Evaluasi formatif meliputi evaluasi yang dilakukan sebelum program berjalan, atau sedang dalam pelaksanaan, atau setelah program selesai dan dapat diteliti hasil dan dampaknya; dan 2.) Evaluasi sumatif, yakni evaluasi yang dilakukan untuk beberapa periode atau tahun, sehingga memerlukan pengumpulan data untuk beberapa tahun yang dievaluasi (Akdon, 2006; Astuti, Saudi, \& Sinaga, 2020).

\section{SIMPULAN}

Implementasi manajemen strategik dalam usaha peningkatan mutu pendidikan di Gunungkidul dilakukan dengan melibatkan semua stakeholder dalam setiap tahapan manajemen strategik. Dalam merumuskan strategi (formulating), mengimplementasikan strategi (implementating) dan mengevaluasi strategi (evaluating), semua unsur lembaga pendidikan Muhammadiyah di Kabupaten Gunungkidul harus terlibat di dalamnya, karena dengan adanya keterlibatan semua stakeholder akan mempermudah dalam meningkatkan dan mewujudkan lembaga pendidikan Muhammadiyah yang bermutu dan kompetitif. Adapun implementasi strategi yang dilakukan dalam meningkatkan mutu sekolah adalah dengan menjabarkan dan melaksanakan semua strategi yang telah dirumuskan dalam bentuk kegiatan-kegiatan terprogram dan terukur. Tahapan terakhir implementasi ini dilakukan evaluasi strategi yang digunakan adalah melalui rapat formal maupun informal.

Selain itu, ada beberapa strategi yang harus menjadi perhatian khusus lembaga pendidikan Muhammadiyah di Kabupaten Gunungkidul, yaitu pengembangan kurikulum, peningkatan sumber daya manusia dan sarana prasarana, peningkatan prestasi peserta didik dan membangun citra lembaga. Keberadaan sumber daya manusia yang masih muda dan berkualitas juga ditopang dengan anggaran biaya yang cukup besar dipastikan dapat membantu mewujudkan lembaga pendidikan Muhammadiyah di Kabupaten Gunungkidul yang bermutu.

\section{DAFTAR PUSTAKA}

Akdon, D. (2006). Manajemen strategik untuk manajemen pendidikan. Bandung: Alfabeta.

Astuti, M., Saudi, M. H. M., \& Sinaga, O. (2020). Marketing strategy planning based on positioning to improve the number of students. International Journal of Psychosocial Rehabilitation, 24(2).

Aziz, A. (2015). Peningkatan mutu pendidikan. Jurnal Studi Islam, 10(2), 1-13. Retrieved from http://ejournal.kopertais4.or.id/tapalkuda/index.php/pwahana/article/view/2688/1972

Dakir, D. (2004). Perencanaan dan pengembangan kurikulum. Yogyakarta: PT. Rineka Cipta.

Darmadji, A. (2008). Implementasi total quality management sebagai upaya peningkatan mutu pendidikan di MAN Model Yogyakarya. EL TARBAWI, 1(2), 181-200. doi:https://doi.org/10.20885/tarbawi.voll.iss2.art3

Fattah, N. (1999). Landasan manajemen pendidikan. Bandung: PT Remaja Rosdakarya.

Fullan, M. (1994). Symposium '94 on Restructuring Education, Sponsored by the California Center for Restructuring Schools.

Hambali, M., \& Luthfi, M. (2017). Manajemen kompetensi guru dalam meningkatkan daya saing. Journal of Management in Education, 2(1), 10-19. Retrieved from http://repository.uinmalang.ac.id/2208/1/2208.pdf 
68 - Jurnal Akuntabilitas Manajemen Pendidikan

Hamid, E. S., Sairin, S., \& Nasir, M. S. (2005). Profesionalisme dan akuntabilitas amal usaha Muhammadiyah: Bidang ekonomi dan pendidikan. LPTP, PP Muhammadiyah.

Husna, A. (2019). Eclectic method (combined) in the implementation of expensive qiro'ah. ElMubtada: Journal of Elementary Islamic Education, 1(1). Retrieved from http://jurnal.staiba.ac.id/index.php/el-Mubtada/article/view/114/pdf

Ilyasin, M., \& Nurhayati, N. (2012). Manajemen pendidikan Islam: Konstruksi teoritis dan praktis. Yogyakarta: Aditya Media Pub.

Kurniawan, D. (2017). Pengaruh profesionalisme guru agama terhadap pendidikan karakter siswa sekolah dasar Islam. Idaarah: Jurnal Manajemen Pendidikan, 1(2). doi:https://doi.org/10.24252/idaarah.v1i2.4273

Kurniyati, E. (2019). Implementasi konsep manajemen mutu pendidikan perpsektif pendidikan Islam. Rausyan Fikr: Jurnal Pemikiran \& Pencerahan, 15(1). doi:http://dx.doi.org/10.31000/rf.v15i1.1363

Miles, M. B., Huberman, A. M., \& Saldaña, J. (2014). Qualitative data analysis: A methods sourcebook. California: Sage.

Mulyana, E. (2004). Manajemen berbasis sekolah konsep strategi dan implementasi. Bandung: PT. Remaja Rosdakarya.

Mulyasa, E. (2007). Menjadi kepala sekolah profesional. Bandung: PT Remaja Rosdakarya.

Mulyasa, E. (2002). Manajemen berbasis sekolah konsep strategi dan implikasi. Bandung: PT. Remaja Rosda Karya.

Mursidi, A. (2010). Pengelolaan komite sekolah dalam meningkatkan mutu pendidikan di SD Islam Al Azhar 29 Semarang. IAIN Walisongo.

Mursidi, A. (2013). Pengelolaan komite sekolah dalam meningkatkan mutu pendidikan di SD Islam Al Azhar 29 Semarang. Jurnal Manajemen Pendidikan, 2(1). doi:https://doi.org/10.26877/jmp.v2i1.403

Mutohar, P. M. (2013). Manajemen mutu sekolah: Strategi peningkatan mutu dan daya saing lembaga pendidikan Islam. Sleman: Ar-Ruzz Media.

Najib, K. H., \& Pardjono, P. (2019). Manajemen pengembangan kompetensi guru untuk implementasi Kurikulum 2013 di SMA Negeri Pilot Project Yogyakarta. Jurnal Akuntabilitas Manajemen Pendidikan, 7(1), 50-61. doi:https://doi.org/10.21831/amp.v7i1.9525

Nasir, M. (2013). Pengembangan kurikulum muatan lokal dalam konteks pendidikan Islam di madrasah. HUNAFA: Jurnal Studia Islamika, 10(1), 1. doi:https://doi.org/10.24239/jsi.v10i1.12.1-18

Nasokah, N. (2015). Kompetensi profesionalisasi guru. Manarul Qur'an: Jurnal Ilmiah Studi Islam, 14(1), 101-109. doi:https://doi.org/10.32699/mq.v14i1.908

Novalita, R. (2019). Perbandingan pendidikan negara Belgia dengan negara indonesia. Jurnal Spasial, 4(3), 75-84. doi:https://doi.org/10.22202/js.v4i3.2395

Qomar, M. (2013). Strategi pendidikan Islam. Jakarta: Erlangga.

Rahayuningsih, R. S., Fajaruddin, S., \& Manggalasari, L. C. (2018). The implementation of total quality management in vocational high schools. Psychology, Evaluation, and Technology in Educational Research, 1(1), 31-40. doi:https://doi.org/10.33292/petier.v1i1.20

Rosado, C. (2004). Building your leadership team: value systems, memetics, and education a spiral dynamics approach. In ROSADO CONSULTING for Change in Human Systems.

Sagala, S. (2013). Manajemen strategik dalam peningkatan mutu pendidikan. Bandung: Alfabeta. 
Saputra, T. H. A. (2017). Manajemen strategik peningkatan mutu lembaga pendidikan Islam (Studi multi kasus di MA Muhammadiyah dan SMK Muhammadiyah, Watulimo Trenggalek). IAIN Tulungagung.

Setyoningrum, M. U. (2018). Keefektifan implementasi sistem manajemen mutu (SMM) ISO 9001: 2008 di SMA Negeri Kabupaten Sleman. Jurnal Akuntabilitas Manajemen Pendidikan, 6(1), 22. doi:https://doi.org/10.21831/amp.v6i1.8971

Subarkah, M. A. (2017). Muhammadiyah dan amal usaha di bidang pendidikan. Rausyan Fikr: Jurnal Pemikiran \& Pencerahan, 13(2). doi:http://dx.doi.org/10.31000/rf.v13i2.302

Susanto, A., \& Wibowo, U. B. (2017). Manajemen perubahan sekolah menengah kejuruan di Kabupaten Sleman. Jurnal Akuntabilitas Manajemen Pendidikan, 5(2), 135. doi:https://doi.org/10.21831/amp.v5i2.15659

Umam, M. K. (2017). Strategi alternatif memajukan lembaga pendidikan Islam di pedesaan berbasis sekolah excellent perspektif kompetitif kotemporer. Proceedings of Annual Conference for Muslim Scholars, 2, 769-776. Retrieved from http://proceedings.kopertais4.or.id/index.php/ancoms/article/view/79

Zahra, D. N. (2019). Development of Islamic education curriculum model Curriculum 2013 (K13). AL-HAYAT: Journal of Islamic Education, 3(1), 38. doi:https://doi.org/10.35723/ajie.v3i1.50

Zamroni, Z. (2011). Dinamika peningkatan mutu. Jakarta: Gavin Kalam Utama. 